\title{
Solid state and sub-cooled liquid vapour pressures of cyclic aliphatic dicarboxylic acids
}

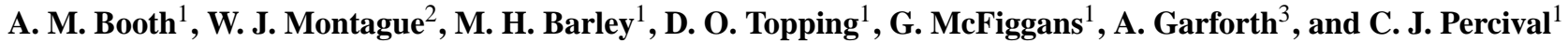 \\ ${ }^{1}$ School of Earth, Environmental and Atmospheric Science, University of Manchester, UK \\ ${ }^{2}$ School of Chemistry, University of Manchester, UK \\ ${ }^{3}$ School of Chemical Engineering and Analytical Science, University of Manchester, UK
}

Received: 19 August 2010 - Published in Atmos. Chem. Phys. Discuss.: 6 October 2010

Revised: 13 January 2011 - Accepted: 17 January 2011 - Published: 21 January 2011

\begin{abstract}
Knudsen Effusion Mass Spectrometry (KEMS) has been used to measure for the first time the solid state vapour pressures of a series of aliphatic cyclic dicarboxylic acids with increasing ring size. Additionally the atmospherically important compounds; cis-pinonic acid and levoglucosan were also measured. Differential Scanning Calorimetry (DSC) was used to measure melting points, enthalpies and entropies of fusion, which were used to determine sub-cooled liquid vapour pressures for the compounds. The sub-cooled liquid vapour pressure of straight chain, branched and cyclic dicarboxylic acids was compared to a selection of estimation methods.
\end{abstract}

\section{Introduction}

The direct and indirect impacts of atmospheric aerosols are one of the greatest uncertainties in our understanding of radiative forcing (Solomon et al., 2007). Organic compounds in aerosols are ubiquitous (Zhang et al., 2007; Hallquist et al., 2009) and incredibly varied, with possibly hundreds of thousands of compounds (Goldstein and Galbally, 2007). Gas (volatile organic compounds, VOC) to particle partitioning is responsible for a considerable fraction of organic aerosols $(\mathrm{OA})$, and is frequently described by an equilibrium based absorptive partitioning model (Pankow, 1994). The vapour pressures of the components making up the OA are an important parameter in absorptive partitioning (Pankow, 1994). Accurate vapour pressure estimation methods and

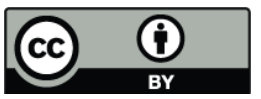

Correspondence to: A. M. Booth (alastair.booth@manchester.ac.uk) experimental data to test them against are important in improving our understanding of the $\mathrm{OA}$ fraction in atmospheric aerosols.

Significant emissions of volatile organic compounds (VOC) arise from biogenic sources and global rates have been estimated at $\sim 800 \mathrm{TgCy}^{-1}$ (Fowler et al., 2009). About $50 \%$ of the biogenic VOC emissions are thought to be isoprene (Guenther et al., 2006), monoterpenes contribute $10-15 \%$, and sesquiterpenes are also emitted in small quantities (Fowler et al., 2009). The vast emissions of isoprene in particular, and terpenes in general means that if they yield a small amount of aerosol, then the effect on the global organic aerosol budget would be substantial (Henze and Seinfeld, 2006). Products from terpene oxidation such as pinic and pinonic acid have been found in atmosphere aerosols (e.g. Boy et al., 2004; Fu et al., 2009).

There are many methods of estimating pure component vapour pressures, but most of the experimental data collected for fitting these methods are from intermediate or high vapour pressure compounds. Some of the estimation methods can give errors in vapour pressure of several orders of magnitude for multifunctional compounds at ambient temperatures (Barley and McFiggans, 2010; Booth et al., 2010). There are several experimental methods available for very-low vapour pressure measurements including Tandem Differential Mobility Analysis (TDMA) (Bilde and Pandis, 2001; Bilde et al., 2003; Mønster et al., 2004; Koponen et al., 2007; Riipinen et al., 2007; Froesch et al., 2010; Salo et al., 2010), White light resonance spectroscopy (Zardini et al., 2006), Temperature Programmed Desorption (TPD) (Cappa et al., 2007; Chattopadhyay and Zieman, 2005), Electrodynamic Balance (EDB) (Pope et al., 2010; Soonsin et al., 2010), Optical tweezers (Pope et al., 2010), Knudsen

Published by Copernicus Publications on behalf of the European Geosciences Union. 
Effusion Mass-loss (Riberio da Silva et al., 1999, 2001) and Knudsen Effusion Mass Spectrometry (KEMS) (Booth et al., 2009). They have been previously used to study straight chain (Riberio da Silva et al., 1999; Bilde et al., 2003; Chattopadhyay and Zieman 2005; Zardini et al., 2006; Koponen et al., 2007; Riipinen et al., 2007; Cappa et al., 2007; Salo et al., 2010; Pope et al., 2010; Soonsin et al., 2010), branched (Riberio da Silva et al., 2001; Mønster et al., 2004; Booth et al., 2010), cyclic (Bilde and Pandis, 2001) and substituted (Chattopadhyay and Zieman 2005; Froesch 2010, Booth et al, 2010) dicarboxylic acids which have been identified in the atmosphere (Hallquist et al., 2009; Kawamura et al., 1996; Sempere and Kawamura, 1994; Gao et al., 2004; Kawamura et al., 2005) as likely products of VOC oxidation. These dicarboxylic acids are solids at room temperature and pressure; however, current gas/particle partitioning models use the sub-cooled liquid reference state, as do activity models (Booth et al., 2010; Riipinen et al., 2007). The sub-cooled liquid is the metastable liquid which exists if solidification does not occur at temperatures below that of the triple point. On a pressure-temperature $(P, T)$ phase diagram, it is a line that forms an extension to the liquid phase vapour pressure line below the triple point temperature.

In this work KEMS combined with Differential Scanning Calorimetry (DSC) has been use to measure solid state vapour pressures and determine, using a thermodynamic relationship, sub-cooled liquid vapour pressures. As part of a larger data set, measurements have been made here for the first time of a systematic series of cyclic dicarboxylic acids with increasing ring sizes. Cyclic acids and diacids are possible SOA products of biogenic terpeneoid VOC oxidation where the cyclic moiety has been retained. These results will also determine the skill of the estimation methods for compounds with cyclic backbones. In addition, the vapour pressure of levoglucosan, a tracer for biomass burning (Simoneit et al., 1999), has also been measured.

\section{Theory}

\subsection{Sub-cooled correction}

The sub-cooled liquid vapour pressure is derived from the value measured above the solid state using the following equation (Prausnitz et al., 1986):

$\ln \frac{P_{1}}{P_{\mathrm{s}}}=\frac{\Delta H_{\text {fus }}}{R T_{\mathrm{m}}}\left(\frac{T_{\mathrm{m}}}{T}-1\right)-\frac{\Delta c_{\mathrm{p}, \mathrm{sl}}}{R}\left(\frac{T_{\mathrm{m}}}{T}-1\right)+\frac{\Delta c_{\mathrm{p}, \mathrm{sl}}}{R} \ln \frac{T_{\mathrm{m}}}{T}$

where $P$ is the vapour pressure with the subscript $s$ referring to the solid and $l$ to the sub-cooled liquid phase, $\Delta H_{\text {fus }}$ is the enthalpy of fusion $\left(\mathrm{J} \mathrm{mol}^{-1}\right), \Delta c_{\mathrm{p}, \mathrm{sl}}$ denotes the change in heat capacity between the liquid and solid state at the melting point $\left(\mathrm{J} \mathrm{mol}^{-1} \mathrm{~K}^{-1}\right), T$ is the temperature $(\mathrm{K})$ and $T_{\mathrm{m}}$ is the melting point (K). Strictly speaking the triple point $T_{\mathrm{t}}$ should be used as per the definition of sub-cooled liquid in Sect. 1, but $T_{\mathrm{m}}$ is more commonly used and is typically within $1 \mathrm{~K}$ of $T_{\mathrm{t}}$ for small organic acids. The sub-cooled liquid vapour pressure also allows more direct comparison with theoretical vapour pressure estimation methods which predict the subcooled state (e.g. Nannoolal et al., 2008; Moller et al., 2008).

\subsection{Vapour pressure estimates}

Many predictive methods exist for vapour pressure (Barley and McFiggans, 2010). Here we use three methods which have previously been used in estimating vapour pressure for atmospheric compounds (Barley and McFiggans, 2010; Booth et al., 2010). The 3 methods have been chosen as they were reported to be the best methods for a test set of 45 low volatility compounds by Barley and McFiggans (2010) and they have been used in conjunction with KEMS measurements previously (Booth et al., 2010). The vapour pressure equations (referred to here as the vapour pressure methods) describe the vapour pressure, which varies exponentially with temperature, (see Eq. 2) as a function of several inputs, such as group contribution parameters, or the vapourisation entropy. All the methods here also require the normal boiling point, $T_{\mathrm{b}}$, to be calculated separately. Together they described the vapour pressure from 1 atmosphere at the normal boiling point down the pressure at the required temperature, in this case $298 \mathrm{~K}$. The three vapour pressure methods used are the Nannoolal et al. (2008) and the Moller et al. (2008) methods both with $T_{\mathrm{b}}$ by Nannoolal et al. (2004), and the Myrdal and Yalkowsky (1997) method with $T_{\mathrm{b}}$ by Stein and Brown (1994). The methods are briefly outlined here, for more detailed descriptions see Barley and McFiggans (2010) or Booth et al. (2010).

The Nannoolal et al. (2004) estimation method uses group contribution calculations with primary and secondary groups and group interactions (207 groups). It was used to calculate both normal boiling points (Nannoolal et al., 2004) and then the slope of the vapour pressure line (Nannoolal et al., 2008). The Moller et al. (2008) method is a refinement of the Nanoolal et al. (2008) method. It features an additional term to improve predictions for aliphatic alcohols and carboxylic acids, new size dependent groups to improve predictions for several functional groups, and new hydrocarbon groups. The Myrdal and Yalkowsky (1997) method requires a source of boiling point $\left(T_{\mathrm{b}}\right)$ estimations. In this work the group contribution method of Stein and Brown (1994) (85 groups), which is adapted from an earlier method (Joback and Reid, 1987), was used to provide $T_{\mathrm{b}}$. This was then used with the equations of Myrdal and Yalkowsky (1997) which uses the flexibility of the molecular structure and hydrogen bond number to estimate the entropy of vapourisation $\Delta S_{\text {vap }}$. 


\section{Experimental}

\subsection{Knudsen effusion mass spectrometry}

Samples of 1,1-cyclopropane dicarboxylic acid (>97\%), cis-pinonic acid (>98\%), 1,1-cyclobutane dicarboxylic acid (>99\%), 1,2-cyclopentpane dicarboxylic acid (>98\%), 1,3cyclohexane dicarboxylic acid $(>99 \%)$ and levoglucosan (>99\%) were purchased from Sigma-Aldrich and used with no further preparation. Solid state vapour pressures were determined using a custom built Knudsen Effusion Mass Spectrometer (Booth et al., 2009) consisting of two separately pumped chambers, connected via a gate valve. The first chamber holds the Knudsen cell and the second chamber holds a Balzers-Pffeifer quadrupole mass spectrometer.

The KEMS system is discussed in more detail in Booth et al. (2009), a brief overview of the experimental method is included here. To calibrate, a sample of known vapour pressure is placed in the temperature controlled Knudsen cell (in this case malonic acid, using vapour pressure values of ln $P(\mathrm{~Pa})=29.54-11058.97 / T(\mathrm{~K})$ Booth et al., 2009). The cell has a chamfered effusing orifice with a size $\leq 1 / 10$ the mean free path of the gas molecules in the cell. This ensures the orifice does not significantly disturb the thermodynamic equilibrium of the samples in the cell (Hilpert, 2001). The resulting molecular beam is ionised by $70 \mathrm{eV}$ electron impact, then sampled by the mass spectrometer. After correcting for the ionization cross section of the calibration compound, this produces a signal proportional to the vapour pressure.

After this calibration a sample of unknown vapour pressure can be measured. During sample change the first chamber with the Knudsen cell is isolated via the gate valve and vented to air allowing the ioniser filament to be left on. The unknown vapour pressures can be determined from the intensity of the mass spectrometer signal of the compound in question. If the Knudsen number, the ratio of the mean free path of molecules to the size of the effusion orifice, is high enough then effusing gas does not significantly disturb the equilibrium in the cell (Booth et al., 2009; Hilpert, 1991, 2001) making the steady state pressure, as measured by the KEMS, as close as possible to the equilibrium vapour pressure.

Once the vapour pressure, $P$, has been determined at a number of different temperatures further thermodynamic data can be obtained using the Clausius-Clapeyron equation (Hilpert, 2001);

$\ln P=\frac{\Delta H_{\mathrm{sub}}}{R T}+\frac{\Delta S_{\mathrm{sub}}}{R}$

where $T$ is the temperature, $R$ is the ideal gas constant and $\Delta H_{\text {sub }}$ and $\Delta S_{\text {sub }}$ are the enthalpies and entropies of sublimation respectively. $P$ was obtained over a range of $20 \mathrm{~K}$ in this work, starting at $298 \mathrm{~K}$. The reported solid state $P_{298}$ vapour pressures are calculated from the linear fit of $\ln P$ vs. $1 / T$ used in the Clausius-Clapeyon equation.

\subsection{Differential scanning calorimetry}

The thermochemical data was obtained using the same procedure as in Booth et al. (2010) and is repeated here: Melting points $\left(T_{\mathrm{m}}\right)$ and enthalpies of fusion $\left(\Delta H_{\text {fus }}\right)$ were measured using a TA instruments Q200 DSC with a heating rate of $10 \mathrm{C} \mathrm{min}^{-1}$ up to $200^{\circ} \mathrm{C}$. $5-10 \mathrm{mg}$ of sample was measured out and recorded using a microbalance, the sample was then pressed into a hermetically sealed aluminium DSC pan. A purge gas of $\mathrm{N}_{2}$ was used with a flow rate of $30 \mathrm{ml} \mathrm{min}^{-1}$. The reference was an empty sealed pan of the same type. Data processing was performed using the "Universal Analysis" software supplied with the instrument. $\Delta c_{\mathrm{p}, \mathrm{sl}}$ is frequently estimated using one of three assumptions, based on empirical evidence; $\Delta c_{\mathrm{p}, \mathrm{sl}}=0$ (Yalkowsky, 1981; Prausnitz et al., 1986), $\Delta c_{\mathrm{p}, \mathrm{sl}}=0.5 \Delta S_{\text {fus }}$ (Tsonopoulos, 1970) and $\Delta c_{\mathrm{p}, \mathrm{sl}}=\Delta S_{\text {fus }}$ (Mauger et al., 1972; Grant et al., 1984). $\Delta c_{\mathrm{p}, \mathrm{sl}}=\Delta S_{\text {fus }}$ is used in this work, which is calculated using DSC measurements and $\Delta S_{\text {fus }}=\Delta H_{\text {fus }} / T_{\mathrm{m}}$. Booth et al. (2010) compared this assumption with literature values of $\Delta c_{\mathrm{p}, \mathrm{sl}}$ for the $\mathrm{C}_{3}-\mathrm{C}_{6}$ straight chain diacids and it can lead to differences of 10-20\% in the sub-cooled liquid vapour pressure. The $\Delta c_{\mathrm{p}, \mathrm{sl}}=0.5 \Delta S_{\text {fus }}$ assumption leads to differences of $15-70 \%$, and $\Delta c_{\mathrm{p}, \mathrm{sl}}=0$ gives differences between 35 and $260 \%$ for the $\mathrm{C}_{3}-\mathrm{C}_{6}$ diacids vs. literature $\Delta c_{\mathrm{p}, \mathrm{sl}}$.

\section{Results and discussions}

\subsection{Experimental vapour pressures}

Table 1 shows the $P_{298 \text { solid, }} \Delta H_{\text {sub }}$ and $\Delta S_{\text {sub }}$ obtained by fitting Eq. (2) to the vapour pressure data in Table 2 measured using KEMS. The data are shown in Figs. 1 and 2. Table 1 also shows literature results for some related compounds, included for comparison with our results. The Table $1 \mathrm{com}-$ pounds include literature straight chain and branched diacids with the same O/C ratios as those measured in this study. Where possible we have used previous KEMS (Booth et al., 2009, 2010) and Knudsen mass loss data from Riberio da Silva et al. (2001), the remaining literature measurements are using TDMA by the Bilde group which tend to agree well with KEMS results, this is to ensure as much consistency as possible when comparing the relative differences between cyclic and straight chain diacids. Table 3 shows the thermochemical data obtained from DSC and the sub-cooled liquid vapour pressure determined from them and the KEMS results. Table 3 also shows sub-cooled liquid vapour pressures calculated in this work from available literature data and the vapour pressures in Table 1. The difference between the solid state and sub-cooled liquid, which are dependant on $T_{\mathrm{m}}$ and $\Delta H_{\text {fus }}$ are illustrated in Fig. 3. The error on the solid state is based on repeated measurements of the straight chain diacids in Booth et al. (2009), the sub-cooled liquid error is from Booth et al. (2010) and is the total error from the solid state 
Table 1. Solid state vapour pressure, enthalpies and entropies of sublimation measured in this work. Estimated maximum error on $P_{298}$ solid $\pm 40 \%$. Also shown, literature solid state vapour pressures $\left(P_{298}\right)$ and calculated $\Delta H_{\text {sub }}, \Delta S_{\text {sub }}$ (where available) for straight chain, branched and cyclic diacids. ${ }^{a}$ HTDMA, Bilde and Pandis (2001) ${ }^{b}$ KEMS, Booth et al. (2009) ${ }^{c}$ KEMS, Booth et al. (2010) ${ }^{d}$ HTDMA, Bilde et al. (2003) ${ }^{\text {e }}$ HTDMA, Mønster et al. (2004) ${ }^{\diamond}$ Knudsen Mass-loss, Riberio da Silva et al. (2001) extrapolated to 298 K.

$P_{298 \text { solid }}(\mathrm{Pa})$
solid state $\begin{array}{r}\Delta H_{\text {sub }} \\ \left(\mathrm{kJ} \mathrm{mol}^{-1}\right)\end{array} \quad \begin{array}{r}\Delta S_{\text {sub }} \\ \left(\mathrm{J} \mathrm{mol}^{-1} \mathrm{~K}^{-1}\right)\end{array}$

vapour pressure, the assumption of $\Delta c_{\mathrm{p}, \mathrm{sl}}=\Delta S_{\mathrm{fus}}$, and the change from using the highest and lowest values for $\Delta H_{\text {fus }}$ and $T_{\mathrm{m}}$ in the literature.

\subsection{1 $C_{5}$ diacids}

The aliphatic $\mathrm{C}_{5}$ diacids; 1,1 cyclopropane dicarboxylic, glutaric and 2-methyl succinic acid, decrease in solid state vapour pressure by a factor of 1.4 for cyclic to straight chain and 1.7 for straight to branched, these are similar to the 
Table 1. Continued.

\begin{tabular}{|c|c|c|c|c|}
\hline Structure & Name & $\begin{array}{r}P_{298 \text { solid }}(\mathrm{Pa}) \\
\text { solid state }\end{array}$ & $\begin{array}{r}\Delta H_{\text {sub }} \\
\left(\mathrm{kJ} \mathrm{mol}^{-1}\right)\end{array}$ & $\begin{array}{r}\Delta S_{\text {sub }} \\
\left(\mathrm{J} \mathrm{mol}^{-1} \mathrm{~K}^{-1}\right)\end{array}$ \\
\hline & pinic acid ${ }^{\mathrm{a}}$ & $4.27 \times 10^{-5}$ & 109 & - \\
\hline & glutaric acid ${ }^{b}$ & $4.21 \times 10^{-4}$ & 123 & 208 \\
\hline & adipic acid ${ }^{b}$ & $3.28 \times 10^{-6}$ & 119 & 231 \\
\hline & pimelic acid ${ }^{\mathrm{d}}$ & $5.10 \times 10^{-5}$ & 147 & - \\
\hline & suberic acid ${ }^{\mathrm{d}}$ & $1.20 \times 10^{-6}$ & 184 & - \\
\hline & 2-methyl succinic acid ${ }^{c}$ & $2.54 \times 10^{-4}$ & 100 & 268 \\
\hline & 2-methyl glutaric acid & $1.85 \times 10^{-4}$ & 82 & 204 \\
\hline & 3-methyl glutaric acid & $1.77 \times 10^{-4}$ & 86 & 215 \\
\hline & 3,3-dimethyl glutaric acid & $2.30 \times 10^{-3}$ & 60 & - \\
\hline 1 & 2,2-dimethyl glutaric acid & $1.63 \times 10^{-4}$ & 125 & 347 \\
\hline & 3-methyl adipic acide & $1.30 \times 10^{-4}$ & 215 & - \\
\hline
\end{tabular}

reported errors of $\pm 40 \%$. The sub-cooled liquid vapour pressures, which are free of crystal structure effects, show a similar reduction $(\sim 1.6)$ from cyclic to straight. The differences between the $\mathrm{C}_{5}$ acids as solids are similar to those as subcooled liquids, which indicates the crystal structure effects for these solids are negligible.

\subsection{2 $\mathrm{C}_{6}$ diacids}

The $\mathrm{C}_{6}$ diacids; 1,1 cyclobutane, adipic, 2-methyl glutaric and 3-methyl glutaric, show the solid state vapour pressure for the branched being approximately 1.5 times more volatile than the cyclic, but the straight chain results are lower by two orders of magnitude. This suggests a large difference 
Table 2. Solid state vapour pressure data $(\mathrm{Pa})$ at different temperatures.

\begin{tabular}{lrrrrr}
\hline Temperature (K) & 298 & 303 & 308 & 313 & 318 \\
\hline 1,1-cyclopropane diacid & $7.04 \times 10^{-4}$ & $1.31 \times 10^{-3}$ & $2.41 \times 10^{-3}$ & $6.65 \times 10^{-3}$ & $1.74 \times 10^{-2}$ \\
1,1-cyclobutane diacid & $1.09 \times 10^{-4}$ & $2.05 \times 10^{-4}$ & $3.55 \times 10^{-4}$ & $5.67 \times 10^{-4}$ & $9.45 \times 10^{-4}$ \\
1,2-cyclopentane diacid & $5.13 \times 10^{-5}$ & $8.26 \times 10^{-5}$ & $1.02 \times 10^{-4}$ & $1.66 \times 10^{-4}$ & $2.93 \times 10^{-4}$ \\
1,3-cyclohexane diacid & $1.21 \times 10^{-4}$ & $1.83 \times 10^{-4}$ & $2.74 \times 10^{-4}$ & $4.19 \times 10^{-4}$ & $6.66 \times 10^{-4}$ \\
cis-pinonic acid & $1.43 \times 10^{-4}$ & $2.42 \times 10^{-4}$ & $5.03 \times 10^{-4}$ & $1.06 \times 10^{-3}$ & $2.18 \times 10^{-3}$ \\
levoglucosan & $4.83 \times 10^{-5}$ & $6.70 \times 10^{-5}$ & $1.26 \times 10^{-4}$ & $1.66 \times 10^{-4}$ & $2.72 \times 10^{-4}$ \\
\hline
\end{tabular}

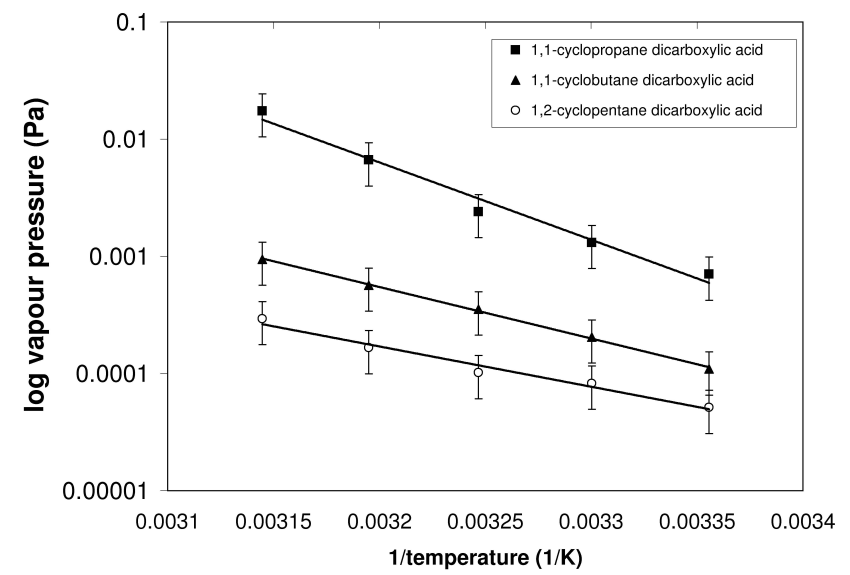

Fig. 1. Log vapour pressure (Pa) vs. $1 /$ Temperature $(1 / \mathrm{K})$ for the data in table 2. Symbols; 1,1-cyclopropane dicarboxylic acid, 1,1cyclobutane dicarboxylic acid, $\bigcirc 1,2$-cyclopentane dicarboxylic acid.

between them in crystal structure. This is a manifestation of the well know odd-even effect of straight chain dicarboxylic acids. Hydrogen bonds formed from carboxylic end groups line up with neighbouring molecules in either a cis- (Odd) or trans- (Even) configuration which makes the crystal structure less or more stable, respectively (Thalladi et al., 2000). The sub-cooled liquid vapour pressures, compared to the $\mathrm{C}_{6}$ cyclic compounds show a $\sim 3$ fold reduction for the straight chain and a 1.5 factor increase for the branched.

\subsection{3 $\quad \mathrm{C}_{7}$ and $\mathrm{C}_{8}$ diacids}

The $\mathrm{C}_{7}$ and $\mathrm{C}_{8}$ diacid solid state vapour pressures show a similar pattern to the $\mathrm{C}_{6}$ and $\mathrm{C}_{5}$. Solid state vapour pressures of the cyclic diacids are similar compared to straight chain diacids when the carbon chain length is odd numbered $\left(C_{5}\right.$ and $\left.C_{7}\right)$, and two orders of magnitude higher when even numbered. This shows that none of the cyclic diacids have the very stable crystal structure of the even numbered straight chain diacids; succinic, adipic and suberic etc. The subcooled liquid vapour pressures all show the straight chain molecules with a lower pressure than the cyclic isomer by

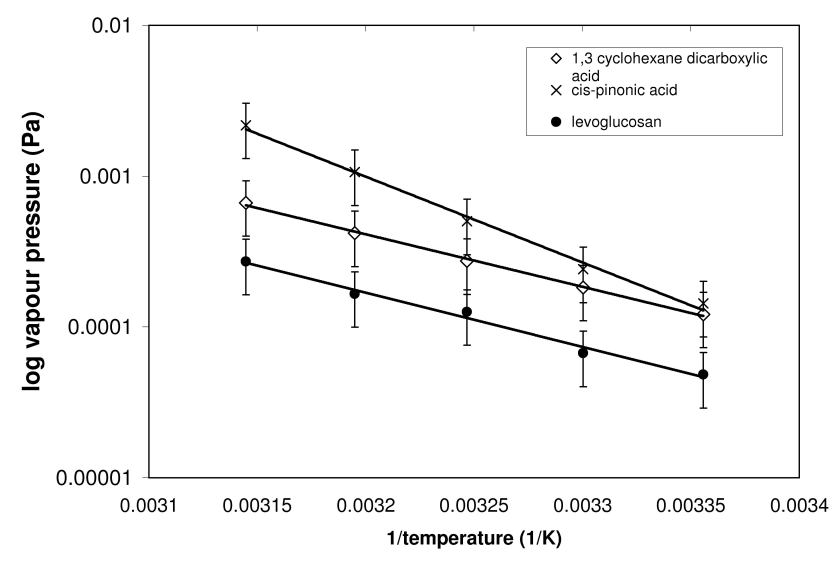

Fig. 2. Log vapour pressure $(\mathrm{Pa})$ vs. $1 /$ Temperature $(1 / \mathrm{K})$ for the data in Table 2. $\times$ cis-pinonic acid, $\diamond 1,3$-cyclohexane dicarboxylic acid, • levoglucosan.

a factor of 1.3 for $\mathrm{C}_{7}$ and 20 for $\mathrm{C}_{8}$. The branched $\mathrm{C}_{7}$ diacids do not have the literature data for $T_{\mathrm{m}}$ and $\Delta H_{\text {fus }}$ to do a sub-cooled liquid correction so only the solid state are available. 3-methyl adipic acid and 2,2-dimethyl glutaric acid have roughly the same vapour pressure, which is 3 times higher than the $\mathrm{C}_{7}$ straight chain and cyclic diacid. 3,3dimethyl glutaric acids is much more volatile with a vapour pressure 15 times that of the other two branched $\mathrm{C}_{7}$ diacids.

\subsection{4 $\mathrm{C}_{5}-\mathrm{C}_{8}$ cyclic diacids}

The sub-cooled liquid vapour pressure shows a similar trend to the solid state vapour pressures but are even closer to each other, within error the $\mathrm{C}_{5}, \mathrm{C}_{6}$ and $\mathrm{C}_{8}$ sub-cooled liquid are the same. The solid state vapour pressure falls from $\mathrm{C}_{5}$ to $\mathrm{C}_{7}$ and rises by $\mathrm{C}_{8}$. The slightly lower solid state vapour pressure for 1,2 cyclopentane dicarboxylic acid compared to the other cyclics may be explained simply by that compound having a more stable crystal structure, but that does not explain the difference in sub-cooled liquid vapour pressures which are independent of crystal structure effects. The enthalpy of sublimation, $\Delta H_{\text {sub }}$, decreases rapidly as the ring size increases, from $126 \mathrm{KJ} \mathrm{mol}^{-1}$ for $\mathrm{C}_{5}$ 
Table 3. Sub-cooled liquid vapour pressures, melting points, enthalpies and entropies of fusion from DSC measurements and correction of solid vapour pressures in Table 1. Estimated maximum error on $P_{298}$ sub-cooled $\pm 75 \%$. Also shown are sub-cooled liquid vapour pressures derived from literature $P_{298}$ solid, $\Delta H_{\text {fus }}$ and $T_{\mathrm{m}}$ (1) ${ }^{\text {a }}$ Booth et al. (2010), (2) ${ }^{+}$Bilde et al. (2003) with $\Delta H_{\text {fus }}$ and $T_{\mathrm{m}}$ from Roux et al. (2005).

\begin{tabular}{|c|c|c|c|c|c|}
\hline Name & $\begin{array}{r}P_{298} \text { sub-cooled } \\
\text { liquid }(\mathrm{Pa})\end{array}$ & $\begin{array}{l}\text { Ratio of sub-cooled } \\
\text { liquid to solid } P_{298}\end{array}$ & $T_{\mathrm{m}}(\mathrm{K})$ & $\begin{array}{r}\Delta H_{\text {fus }} \\
\left(\mathrm{kJ} \mathrm{mol}^{-1}\right)\end{array}$ & $\begin{array}{r}\Delta S_{\text {fus }} \\
\left(\mathrm{J} \mathrm{mol}^{-1} \mathrm{~K}^{-1}\right)\end{array}$ \\
\hline 1,1-cyclopropane diacid & $3.10 \times 10^{-3}$ & 5.2 & 413.0 & 17.4 & 42.1 \\
\hline 1,1-cyclobutane diacid & $6.47 \times 10^{-3}$ & 5.7 & 433.2 & 16.8 & 38.7 \\
\hline 1,2-cyclopentane diacid & $3.47 \times 10^{-4}$ & 7.0 & 428.6 & 19.1 & 44.5 \\
\hline 1,3-cyclohexane diacid & $4.60 \times 10^{-4}$ & 3.9 & 439.0 & 12.9 & 29.4 \\
\hline cis-pinonic acid & $7.78 \times 10^{-4}$ & 6.0 & 377.8 & 23.8 & 63.0 \\
\hline Levoglucosan (1st transition) & $1.35 \times 10^{-4}$ & 2.9 & 385.7 & 13.2 & 34.2 \\
\hline levoglucosan (2nd transition) & $1.93 \times 10^{-4}$ & 1.3 & 455.3 & 3.2 & 7.0 \\
\hline glutaric $^{\mathrm{a}}$ acid & $1.96 \times 10^{-3}$ & 4.6 & 369.0 & 22.0 & 59.7 \\
\hline adpic $^{\mathrm{a}}$ acid & $2.14 \times 10^{-4}$ & 35.7 & 423.0 & 35.9 & 84.8 \\
\hline pimelic $^{\mathrm{b}}$ acid & $2.63 \times 10^{-4}$ & 5.1 & 368.2 & 23.7 & 64.3 \\
\hline suberic $^{\mathrm{b}}$ acid & $2.23 \times 10^{-5}$ & 18.6 & 413.2 & 30.7 & 74.3 \\
\hline 2-methyl succinic ${ }^{a}$ & $5.58 \times 10^{-4}$ & 8.5 & 383.0 & 10.0 & 26.1 \\
\hline 2-methyl glutaric ${ }^{\mathrm{a}}$ & $9.63 \times 10^{-4}$ & 2.2 & 349.0 & 30.3 & 86.7 \\
\hline
\end{tabular}

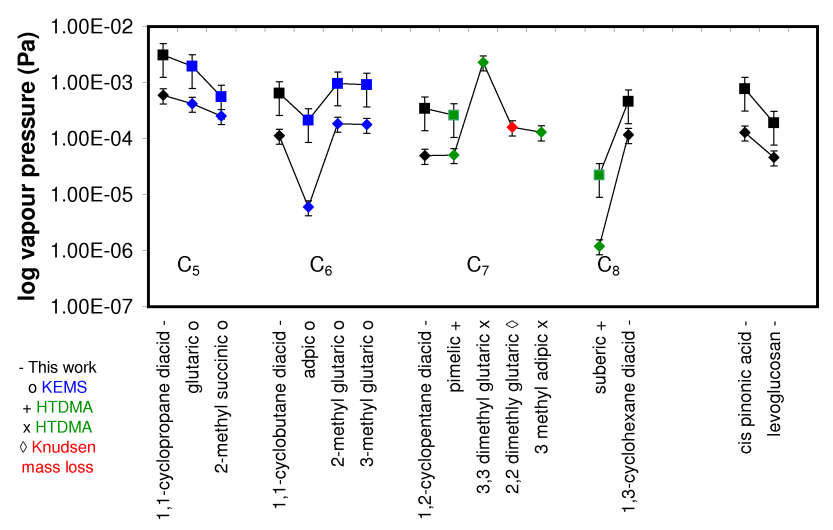

Fig. 3. Solid state $(\diamond)$ and sub-cooled liquid (ם) $P_{298}(\mathrm{~Pa})$. The estimated maximum error is $P_{298}$ solid $\pm 40 \%$ and $P_{298}$ liquid $\pm 75 \%$. - This work, ${ }^{o}$ Booth et al. (2010) ${ }^{+}$Bilde et al. (2003) ${ }^{X}$ Mønster et al. (2004) $\diamond$ Riberio da Silva et al. (2001) extrapolated to $298 \mathrm{~K}$.

to 66 and $67 \mathrm{KJ} \mathrm{mol}^{-1}$ for $\mathrm{C}_{7}$ and $\mathrm{C}_{8}$ respectively. The $\mathrm{C}_{5}$ straight chain diacid has a similar $\Delta \mathrm{H}_{\text {sub }}$ to the cyclic, 123 vs. $126 \mathrm{KJ} \mathrm{mol}^{-1}$, but the pattern for straight chain diacids shows an increasing $\Delta H_{\text {sub }}$ as chain length increases from $123 \mathrm{KJ} \mathrm{mol}^{-1}$ for $\mathrm{C}_{5}$ to $184 \mathrm{KJ} \mathrm{mol}^{-1}$ for $\mathrm{C}_{8}$. This makes for a substantial difference of $117 \mathrm{KJ} \mathrm{mol}^{-1}$ between the cyclic and straight chain $\mathrm{C}_{8}$ diacids. The widening gap with increasing carbon number between the $\Delta H_{\text {sub }}$ for straight chain and cyclic acids may be of consequence for thermal desorption measurements of mixtures of cylic and branched acids as compounds with similar sub-cooled liquid vapour pressure and $\mathrm{O}$ to $\mathrm{C}$ ratio could have very different results after thermal processing and undesired distillation could occur.
The solid state cis-pinonic acid results here are slightly higher than those of Bilde and Pandis (2001) who, due to measurement problems, give an estimated range of 0.5 $1 \times 10^{-4} \mathrm{~Pa}$. The top end of this range however would agree well with our results using the error estimates in Booth et al. (2009, 2010) of $\pm 40 \%$. Levoglucosan exhibits a solid phase transition at $385.7 \mathrm{~K}$ and a melting transition with a small enthalpy of fusion at 456 K (Oja and Suuberg, 1999), we have used the correction in Eq. (1) to adjust for both these transitions and arrive at a final sub-cooled liquid vapour pressure. Oja and Suuberg (1999) have measured levoglucosan below and above this transition getting vapour pressures of $1 \times 10^{-5}$ and $1 \times 10^{-4} \mathrm{~Pa}$, respectively. The first is about a quarter of the value we measure, whereas the the vapour pressure after the transition agrees with our value of $1.35 \times 10^{-4} \mathrm{~Pa}$ within error. Epshtein (1964) has measured levoglucosan from 468 to $528 \mathrm{~K}$, extrapolation of their values down to $298 \mathrm{~K}$ gives a vapour pressure of $1 \times 10^{-3} \mathrm{~Pa}$ which is about 5 times higher than our final sub-cooled liquid vapour pressure of $1.93 \times 10^{-4} \mathrm{~Pa}$, although it should be noted that this extrapolation is for a two parameter Antoine equation fit $200 \mathrm{~K}$ above the desired temperature.

\subsection{Vapour pressure estimates}

Vapour pressure estimates were made using 3 methods; Nannoolal et al. (2004) $T_{\mathrm{b}}$ with Moller et al. (2008) vapour pressures, Nannoolal et al. (2004) $T_{\mathrm{b}}$ with Nannoolal et al. (2008) vapour pressures and Stein and Brown (1994) $T_{\mathrm{b}}$ with Myrdal and Yalkowsky (1997) vapour pressures. It has recently been suggested that the Moller et al. (2008) method becomes increasingly inaccurate as the number of functional groups 
increases (Compernolle et al., 2010), however the majority of compounds in this study only have two groups. Table 4 shows the two different boiling points used, the Stein and Brown (1994) boiling points are higher by $2-7 \mathrm{~K}$ for the cyclic compounds (excepting levoglucosan) but are lower by similar amounts for the straight chain and methyl substituted diacids. Although compared to the differences in $T_{\mathrm{b}}$ values in Barley and McFiggans (2010), the differences here are quite small and the differences from the true $T_{\mathrm{b}}$ are unknown. Systematic errors in $T_{\mathrm{b}}$ can feed through to similar errors in vapour pressure. In this case it could lead to cancelling errors if the calculations were being used on an ensemble of condensing compounds containing both cyclic and straight chain diacids which have an opposing $T_{\mathrm{b}}$ bias. Other boiling point methods are available (ACD/labs) and have been shown to work well for certain classes of compounds, notably amines (Ge et al., 2010). However for these diacids, the ACD/labs $T_{\mathrm{b}}$ does not show a significant overall improvement compared to the Nannoolal et al. (2004) or Stein and Brown (1994) $T_{\mathrm{b}}$ (Ge, 2010), and as the mechanics of the estimation method are not disclosed, further improvement would be difficult.

Table 5 shows the estimated sub-cooled liquid vapour pressures using the 3 estimation methods. For the diacids the Moller/Nannoolal method performs best, on average overestimating vapour pressure by a factor of 2.7. The Nannoolal et al. (2008) method lacks the extra terms of the Moller et al. (2008) method for aliphatic carboxylic acids and its performance (with $T_{\mathrm{b}}$ by Nannoolal) reflects this with an average factor of 12.2 times our sub-cooled vapour pressure values. The Myrdal and Yalkowsky/Stein and Brown overestimated vapour pressures by an average factor of 74 . Cispinonic acid, with a ketone group, causes more problems than the diacids. For this compound the Moller method is an order of magnitude too high, Nannoolal a factor of 70 and Myrdal and Yalkowsky a factor of 200.

Levoglucosan has no acids groups, but aliphatic alcohols, like carboxylic acids groups are known to cause problems for vapour pressure estimates (Booth et al., 2010; Moller et al., 2008). The Moller et al. (2008) method, despite extra terms for aliphatic $\mathrm{OH}$ groups, is the most inaccurate of the vapour pressure methods for this compound. The estimated vapour pressure was out by 3 orders of magnitude, compared to 2 orders of magnitude for the other two methods. The most likely cause for this is the interaction parameter between $\mathrm{OH}$ and ether groups being too high. This is similar to the raising of vapour pressure for compounds with $\mathrm{OH}+\mathrm{COOH}$ groups compared to just $\mathrm{COOH}$ groups, as seen by Chattopadhyay and Ziemen (2005) and Booth et al. (2010). The vapour pressure method comparisons of Compernolle et al. (2010) also note problems with the Moller et al. (2008) method for polyfunctional compounds, although it should be noted that all the methods perform badly with this compound.

Table 6 shows the estimated enthalpies of vapourisation $\left(\Delta H_{\text {vap }}=\Delta H_{\text {sub }}-\Delta H_{\text {fus }}\right)$ compared with those from KEMS/DSC measurements. Barley and McFiggans (2010)
Table 4. Estimated boiling points for cyclic, straight chain and branched diacids using the Nannoolal et al. (2004) and Stein and Brown (1994) methods.

\begin{tabular}{lrr}
\hline Name & $\begin{array}{r}\text { Nannoolal } \\
T_{\mathrm{b}}(\mathrm{K})\end{array}$ & $\begin{array}{r}\text { Stein and Brown } \\
T_{\mathrm{b}}(\mathrm{K})\end{array}$ \\
\hline 1,1-cyclopropane diacid & 558.4 & 563.6 \\
1,1-cyclobutane diacid & 573.2 & 579.7 \\
1,2-cyclopentane diacid & 595.5 & 597.9 \\
1,3-cyclohexane diacid & 609.6 & 611.6 \\
cis-pinonic acid & 562.9 & 569.0 \\
Levoglucosan & 563.5 & 586.9 \\
glutaric acid & 573.8 & 569.0 \\
adipic acid & 587.9 & 583.5 \\
pimelic acid & 601.5 & 597.0 \\
suberic acid & 614.6 & 609.7 \\
2-methyl succinic acid & 563.6 & 559.8 \\
2-methyl glutaric acid & 578.1 & 574.8 \\
3-methyl glutaric acid & 578.1 & 574.8 \\
\hline
\end{tabular}

in their study of vapour pressure methods noted that most of the error for the methods they looked at came from the estimation of the boiling point, and slope of the vapour pressure curve (enthalpy of vapourisation) estimates were generally much easier to get right. The Moller/Nannoolal and Nannoolal/Nannoolal methods here both use the same boiling point, but for most of the compounds there is an order of magnitude difference in the predicted vapour pressure at $298 \mathrm{~K}$ which can only come from the difference in predicted $\Delta H_{\text {vap }}$ between them. This should not be a complete suprise however as the changes to the Nannoolal et al. (2008) method that the Moller et al. (2008) is based on come from extra terms for carboxylic acids, which will obviously have a big impact for the diacids. The different methods show consistent bias in $\Delta H_{\text {vap }}$ for the diacids measured in this study. The Moller et al. (2008) method, excepting levoglucosan, always estimates a higher value for $\Delta H_{\text {vap }}$ than Nannoolal et al. (2008) which predicts higher $\Delta H_{\text {vap }}$ values than Myrdal and Yalkowsky (1997). The $\Delta H_{\text {vap }}$ estimates seem very good for the $\mathrm{C}_{5}$ diacids (typically within $20 \mathrm{KJ} \mathrm{mol}^{-1}$ or less) but as the number of carbon atoms in the molecule increases the behaviour of the straight chain and cyclic diacids diverge. $\Delta H_{\text {vap }}$ increases with carbon number for straight chain diacids and $\Delta H_{\text {vap }}$ decreases with increasing carbon number for cyclic diacids. The estimation methods however, do not significantly change their estimates, for example there is only a range of $23 \mathrm{KJ} \mathrm{mol}^{-1}$ between the highest and lowest estimate for $\Delta H_{\text {vap }}$ using the Nannoolal method, but the experimental methods vary by $106 \mathrm{KJ} \mathrm{mol}^{-1}$. In spite of this the estimation methods can sometimes give good $P_{298}$ values, as opposing errors in $\Delta H_{\mathrm{vap}}$ and $T_{\mathrm{b}}$ can cancel out. 
Table 5. Estimated sub-cooled liquid vapour pressures. The ratio of estimated to measured sub-cooled liquid vapour pressure in brackets.

\begin{tabular}{lrrrr}
\hline & $\begin{array}{r}\text { KEMS } P_{298 \text { liquid }}(\mathrm{Pa}) \\
\end{array} \quad \begin{array}{r}\text { Moller/Nannoolal } \\
P_{298 \text { liquid }}(\mathrm{Pa})\end{array}$ & $\begin{array}{r}\text { Nannoolal/Nannoolal } \\
P_{298 \text { liquid }}(\mathrm{Pa})\end{array}$ & $\begin{array}{r}\text { Myrdal and Yalkowsky/Stein } \\
\text { and Brown } P_{298 \text { liquid }}(\mathrm{Pa})\end{array}$ \\
\hline 1,1-cyclopropane diacid & $3.1 \times 10^{-3}$ & $5.5 \times 10^{-3}(1.8)$ & $4.5 \times 10^{-2}(14.4)$ & $1.2 \times 10^{-1(37.0)}$ \\
1,1-cyclobutane diacid & $6.5 \times 10^{-3}$ & $2.5 \times 10^{-3}(3.8)$ & $1.4 \times 10^{-2}(21.2)$ & $5.3 \times 10^{-2}(81.6)$ \\
1,2-cyclopentane diacid & $3.5 \times 10^{-4}$ & $4.9 \times 10^{-4}(1.4)$ & $2.8 \times 10^{-3}(8.0)$ & $2.1 \times 10^{-2}(60.8)$ \\
1,3-cyclohexane diacid & $4.6 \times 10^{-4}$ & $1.7 \times 10^{-4}(0.4)$ & $7.5 \times 10^{-4}(1.6)$ & $1.1 \times 10^{-2}(23.4)$ \\
cis-pinonic acid & $7.8 \times 10^{-4}$ & $9.7 \times 10^{-3}(12.5)$ & $6.1 \times 10^{-2}(78.2)$ & $1.7 \times 10^{-1}(223.7)$ \\
Levoglucosan & $1.9 \times 10^{-4}$ & $1.0(5233)$ & $4.1 \times 10^{-3}(217.8)$ & $3.2 \times 10^{-2}(164.9)$ \\
glutaric acid & $2.0 \times 10^{-3}$ & $1.3 \times 10^{-3}(0.7)$ & $1.3 \times 10^{-2(6.6)}$ & $6.5 \times 10^{-2}(33.3)$ \\
adipic acid & $2.1 \times 10^{-4}$ & $5.2 \times 10^{-4}(2.4)$ & $3.7 \times 10^{-3}(17.1)$ & $2.9 \times 10^{-2}(133.5)$ \\
pimelic acid & $2.6 \times 10^{-4}$ & $1.8 \times 10^{-4}(0.7)$ & $1.0 \times 10^{-3}(4.0)$ & $1.3 \times 10^{-2}(48.7)$ \\
suberic acid & $2.2 \times 10^{-5}$ & $5.9 \times 10^{-5}(2.7)$ & $3.0 \times 10^{-4}(13.3)$ & $5.8 \times 10^{-3}(262.2)$ \\
2-methyl succinic acid & $5.6 \times 10^{-4}$ & $3.4 \times 10^{-3}(6.0)$ & $2.9 \times 10^{-2}(52.7)$ & $1.3 \times 10^{-1}(223.4)$ \\
2-methyl glutaric acid & $9.6 \times 10^{-4}$ & $1.3 \times 10^{-3}(1.4)$ & $8.2 \times 10^{-3}(8.5)$ & $5.4 \times 10^{-2}(55.7)$ \\
3-methyl glutaric acid & $9.2 \times 10^{-4}$ & $1.3 \times 10^{-3}(1.4)$ & $8.2 \times 10^{-3}(8.0)$ & $5.4 \times 10^{-2}(60.8)$ \\
\hline
\end{tabular}

Table 6. Estimated enthalpies of vapourisation compared with experimental values. KEMS $\Delta H_{\text {vap }}$ calculated usings values from Tables 1 and 3 and $\Delta H_{\text {vap }}=\Delta H_{\text {sub }}-\Delta H_{\text {fus }}$.

\begin{tabular}{lrrrr}
\hline & $\begin{array}{r}\text { KEMS } \Delta H_{\mathrm{vap}} \\
\left(\mathrm{KJ} \mathrm{mol}^{-1}\right)\end{array}$ & $\begin{array}{r}\text { Moller/Nannoolal } \\
\Delta H_{\mathrm{vap}}\left(\mathrm{KJ} \mathrm{mol}^{-1}\right)\end{array}$ & $\begin{array}{r}\text { Nannoolal/Nannoolal } \\
\Delta H_{\mathrm{vap}}\left(\mathrm{KJ} \mathrm{mol}^{-1}\right)\end{array}$ & $\begin{array}{r}\text { Myrdal and Yalkowsky/ } \\
\text { Stein and Brown } \\
\text { and }\end{array}$ \\
& & & 89 & 82 \\
\hline 1,1-cyclopropane diacid & 109 & 103 & 94 & 84 \\
1,1-cyclobutane diacid & 67 & 108 & 101 & 87 \\
1,2-cyclopentane diacid & 47 & 117 & 107 & 89 \\
1,3-cyclohexane diacid & 54 & 124 & 87 & 79 \\
cis-pinonic acid & 85 & 108 & 89 & 86 \\
Levoglucosan & 52 & 102 & 95 & 85 \\
glutaric acid & 101 & 110 & 100 & 88 \\
adipic acid & 83 & 119 & 106 & 90 \\
pimelic acid & 123 & 129 & 112 & 93 \\
suberic acid & 153 & 98 & 91 & 82 \\
2-methyl succinic & 90 & 106 & 97 & 85 \\
2-methyl glutaric & 52 & 106 & 97 & 85 \\
3-methyl glutaric & 58 & & & \\
\hline
\end{tabular}

\section{Conclusions}

Solid state vapour pressures of aliphatic cyclic diacids tend to be very close to that of odd numbered straight chain diacids, but approximately 2 orders of magnitude higher when compared with even numbered straight chain diacids. The subcooled liquid vapour pressures are higher for the cyclic compounds than for comparable straight chain diacids, typically 1.5-3 times higher. The Moller et al. (2008) estimation method with Nannoolal et al. (2004) boiling points provides the best estimates of the cyclic diacids although it significantly over estimates the vapour pressure of levoglucosan. It also overestimates $c i$-pinonic acid by a factor of 10 , but this is still a better result than the other two methods. As with the results of Booth et al. (2010) the main failing of the vapour pressure estimation methods is down to a poor representation of $\mathrm{OH}$ groups and their interactions with other groups.

Acknowledgements. The authors thank NERC for financial support on grant NE/E018181/1 and the EU-funded European Integrated project on Aerosol Cloud Climate and Air Quality interactions (EUCAARI) under contract number/break 036833-2.

Edited by: J. B. Burkholder 


\section{References}

Barley, M. H. and McFiggans, G.: The critical assessment of vapour pressure estimation methods for use in modelling the formation of atmospheric organic aerosol, Atmos. Chem. Phys., 10, 749767, doi:10.5194/acp-10-749-2010, 2010.

Bilde, M. and Pandis, S. N.: Evaporation rates and vapor pressures of individual aerosol species formed in the atmospheric oxidation of $\alpha$ - and $\beta$-pinene, Environ. Sci. Technol., 35, 3344-3349, 2001 2001.

Bilde, M., Svenningsson, B., Monster, J. and Rosenorn, T.: Even - Odd Alternation of Evaporation Rates and Vapor Pressures of C3-C9 Dicarboxylic Acid Aerosols, Environ. Sci. Technol., 37, 1371-1378, 2003.

Booth, A. M., Markus, T., McFiggans, G., Percival, C. J., Mcgillen, M. R., and Topping, D. O.: Design and construction of a simple Knudsen Effusion Mass Spectrometer (KEMS) system for vapour pressure measurements of low volatility organics, Atmos. Meas. Tech., 2, 355-361, doi:10.5194/amt-2-355-2009, 2009.

Booth, A. M., Barley, M. H., Topping, D. O., McFiggans, G., Garforth, A., and Percival, C. J.: Solid state and sub-cooled liquid vapour pressures of substituted dicarboxylic acids using Knudsen Effusion Mass Spectrometry (KEMS) and Differential Scanning Calorimetry, Atmos. Chem. Phys., 10, 4879-4892, doi:10.5194/acp-10-4879-2010, 2010.

Boy, M., Petäjä, T., Dal Maso, M., Rannik, Ü., Rinne, J., Aalto, P., Laaksonen, A., Vaattovaara, P., Joutsensaari, J., Hoffmann, T., Warnke, J., Apostolaki, M., Stephanou, E. G., Tsapakis, M., Kouvarakis, A., Pio, C., Carvalho, A., Römpp, A., Moortgat, G., Spirig, C., Guenther, A., Greenberg, J., Ciccioli, P., and Kulmala, M.: Overview of the field measurement campaign in Hyytiälä, August 2001 in the framework of the EU project OSOA, Atmos. Chem. Phys., 4, 657-678, doi:10.5194/acp-4-657-2004, 2004.

Cappa, D. C., Lovejoy, E. R., and Ravishankara, A. R.: Determination of Evaporation Rates and Vapor Pressures of Very Low Volatility Compounds: A Study of the $\mathrm{C}_{4}-\mathrm{C}_{10}$ and $\mathrm{C}_{12}$ Dicarboxylic Acids, J. Phys. Chem., 111, 3099-3109, 2007.

Chattopadhyay, S. and Zieman, P. J.: Vapor pressures of substituted and unsubstituted monocarboxylic and dicarboxylic acids measured using an improved thermal desorption particle beam mass spectrometry method, Aerosol Sci. Technol., 39, 10851100, 2005.

Compernolle, S., Ceulemans, K., and Müller, J.-F.: Technical Note: Vapor pressure estimation methods applied to secondary organic aerosol constituents from a-pinene oxidation: an intercomparison study, Atmos. Chem. Phys., 10, 6271-6282, doi:10.5194/acp-10-6271-2010, 2010.

Epshtein, Ya. V., Durynina, L. I., and Pashinkin, A. S.: Vapor Pressure of Levoglucosan, Zh. Prikl. Khim. (Leningrad), 37 2543, 1964.

Fowler, D., Pilegaard, K., Sutton, M. A., Ambus, P., Raivonen, M., Duyzer, J., Simpson, D., Fagerli, H., Schjoerring, J. K., Neftel, A., Burkhardt, J., Daemmgen, U., Neirynck, J., Personne, E., Wichink-Kruit, R., Butterbach-Bahl, K., Flechard, C., Tuovinen, J. P., Coyle, M., Fuzzi, S., Gerosa, G., Granier, C., Loubet, B., Altimir, N., Gruenhage, L., Ammann, C., Cieslik, S., Paoletti, E., Mikkelsen, T. N., Ro-Poulsen, H., Cellier, P., Cape, J. N., Isaksen, I. S. A., Horva' th, L., Loreto, F., Niinemets,Ü., Palmer, P. I., Rinne, J., Laj, P., Maione, M., Misztal, P., Monks, P., Nemitz, E., Nilsson, D., Pryor, S., Gallagher, M. W., Vesala, T., Skiba,
U., Brüeggemann, N., Zechmeister-Boltenstern, S., Williams, J., O’Dowd, C., Facchini, M. C., de Leeuw, G., Flossman, A., Chaumerliac, N., and Erisman, J. W.: Atmospheric composition change: Ecosystems-Atmosphere interactions, Atmos. Environ., 43, 5193-5267, 2009.

Frosch, M., Zardini, A. A., Platt, S. M., Müller, L., Reinnig, M.C., Hoffmann, T., and Bilde, M.: Thermodynamic properties and cloud droplet activation of a series of oxo-acids, Atmos. Chem. Phys., 10, 5873-5890, doi:10.5194/acp-10-5873-2010, 2010.

Fu, P., Kawamura, K., Chen, J., and Barrie, L. A.: Isoprene, Monoterpene and Sesquiterpene Oxidation Products in the High Artic Aerosols during Lawte Winrer to Early Summer, Environ. Sci. Technol., 43, 4022-4028, 2009.

Gao, S., Keywood, M., Ng, N. L., Surratt, J., Varutbangkul, V., Bahreini, R., Flagan, R. C., and Seinfeld, J. H.: LowMolecular Weight and Oligomeric Components in Secondary Organic Aerosol from the Ozonolysis of Cycloalkenes and $\alpha$ Pinene, J. Phys. Chem. A., 108, 10147-10164, 2004.

Goldstein, A. H. and Galbally, I. E.: Known and Unexplored Organic Constituents in the Earth's Atmosphere, Environ. Sci. Tech., 41, 1514-1521, 2007.

Grant, D. J. W., Mendizadeh, M., Chow, A. H.-L., and Fairbrother, J. E.: Non-linear van Hoff Solubility Temperature Plots and their Pharmaceutical Interpretation, Int. J. Pharm., 18, 25-38, 1984.

Guenther, A., Karl, T., Harley, P., Wiedinmyer, C., Palmer, P. I., and Geron, C.: Estimates of global terrestrial isoprene emissions using MEGAN (Model of Emissions of Gases and Aerosols from Nature), Atmos. Chem. Phys., 6, 3181-3210, doi:10.5194/acp-63181-2006, 2006.

Ge, X., Wexler, A. S., and Clegg, S. L.: Atmospheric Amines - Part II. Thermodynamic properties and gas/particle partitioning, Atmos. Environ., doi:10.1016/j.atmosenv.2010.10.013Ge, Atmos. Chem. Phys. Discuss., 10, C10429-C10429, 2010.

Hallquist, M., Wenger, J. C., Baltensperger, U., Rudich, Y., Simpson, D., Claeys, M., Dommen, J., Donahue, N. M., George, C., Goldstein, A. H., Hamilton, J. F., Herrmann, H., Hoffmann, T., Iinuma, Y., Jang, M., Jenkin, M. E., Jimenez, J. L., Kiendler-Scharr, A., Maenhaut, W., McFiggans, G., Mentel, Th. F., Monod, A., Prévôt, A. S. H., Seinfeld, J. H., Surratt, J. D., Szmigielski, R., and Wildt, J.: The formation, properties and impact of secondary organic aerosol: current and emerging issues, Atmos. Chem. Phys., 9, 5155-5236, doi:10.5194/acp-95155-2009, 2009.

Henze, D. K. and Seinfeld, J. H.: Global secondary organic aerosol from isoprene oxidation, Geophys. Res. Lett., 33, L09812, doi:10.1029/2006GL025976, 2006

Hilpert, K.: Potential of mass spectrometry for the analysis of inorganic high temperature vapors, Fresen. J. Anal. Chem., 370, 471-478, 2001.

Joback, K. G. and Reid, R. C.: Estimation of pure-component properties from group contributions, Chem. Eng. Commun., 57, 233 243, 1987.

Kawamura, K., Kasukabe, H., and Barrie, L. A.: Source and reaction pathways of dicarboxylic acids, ketoacids and dicarbonyls in arctic aerosols: One year of observations, Atmos. Environ. 30, 1709-1722, 1996.

Kawamura, K., Imai,Y., and Barrie, L. A.: Photochemical Production and Loss of Organic Acids in High Arctic Aerosols During Long-Range Transport and Polar Sunrise Ozone Depletion 
Events, Atmos. Environ., 39, 599-614, 2005.

Koponen, I., Riipinen, I., Hienola, A., Kulmala, M., and Bilde, M.: Thermodynamic properties of Malonic, Succinic and Glutaric acids: Evaporation rates and saturation vapor pressures $\mathrm{Nu}$ cleation and Atmospheric Aerosols, Environ. Sci. Technol., 8, 920-923, 2007.

Mauger, J. W., Paruta, A. N., and Gerraughty, R. J.: Solubilities of Sulfadiazine, Sulfomidine, and Sulfadimethoxine in Several Normal Alcohols, J. Pharm. Sci., 61, 94-97, 1972.

Mønster, J., Rosenørn, T., Svenningsson, B., and Bilde, M.: Evaporation of methyl- and dimethyl-substituted malonic, succinic, glutaric and adipic acid particles at ambient temperatures, J. Aerosol. Sci., 35, 1453-1465, 2004.

Moller, B., Rarey, J., and Ramjugernath, D.: Estimation of the vapour pressure of non-electrolyte organic compounds via group contributions and group interactions, J. Mol. Liq., 143, 52-63, 2008.

Myrdal, P. B. and Yalkowsky, S. H.: Estimating pure component vapour pressures of complex organic molecules, Ind. Eng. Chem. Res., 36, 2494-2499, 1997.

Oja, V. and Suuberg, E. M.: Vapor Pressures and Enthalpies of Sublimation of D-Glucose, D-Xylose, Cellobiose, and Levoglucosan, J. Chem. Eng. Dat., 44, 26-29, 1999.

Nannoolal, Y., Rarey, J., Ramjugernath, D., and Cordes, W.: Estimation of pure component properties Part 1. Estimation of the normal boiling point of non-electrolyte organic compounds via group contributions and group interactions, Fluid Phase Equilibr., 226, 45-63, 2004.

Nannoolal, Y., Rarey, J., and Ramjugernath, D.: Part 3. Estimation of the vapor pressure of non-electrolyte organic compounds via group contributions and group interactions, Fluid Phase Equilibr., 269, 117-133, 2008.

Pankow, J. F.: An absorption-model of gas-particle partitioning of organic-compounds in the atmosphere, Atmos. Environ., 28, 185-188, 1994.

Pope, F.D., Tong H., Dennis-Smither, B. J., Griffiths, P. T., Clegg, S. L., Reid, J. P., and Cox, R. A.: Studies of Single Aerosol Particles Containing Malonic Acid, Glutaric Acid, and Their Mixtures with Sodium Chloride. II. Liquid-State Vapor Pressures of the Acids, J. Phys. Chem. A., 37, 10156-10165, 2010.

Prausnitz, J. M., Lichtenhaler, R. N., and de Azevedo, E. G.: Molecular Thermodynamics of Fluid-phase Equilibria, Prentice-Hall Inc, New Jersey, 419, 1986.

Prausnitz, J. M., Lichtenhaler, R. N., and de Azevedo, E. G.: Molecular Thermodynamics of Fluid-phase Equilibria, Prentice-Hall Inc, New Jersey, 419, 1986.

Riberio da Silva, M. A. V., Monte, M., and Ribeiro, J.: Vapour pressures and the enthalpies and entropies of sublimation of five dicarboxylic acids, J. Chem. Thermodynamics, 31, 1093-1107, 1999.

Riberio da Silva, M. A. V., Monte, M., and Ribeiro, J.: Thermodynamic study on the sublimation of succinic acid and of methyland dimethyl-substituted succinic and glutaric acids, J. Chem. Thermodynamics, 33, 23-31, 2001.
Riipinen, I., Koponen, I., Frank, G., Hyv'arinen, A.-P., Vanhanen, J., Lihavaninen, H., Lehtinen, K., Bilde, M., and Kulmala, M.: Adipic and Malonic Acid Aqueous Solutions: Surface Tensions and Saturation Vapor Pressures, J. Phys. Chem., 111, 1299513002, 2007.

Roux, M. V., Temprado, M., and Chickos, J. S.: Vaporization, fusion and sublimation enthalpies of the dicarboxylic acids from $\mathrm{C}_{4}$ to $\mathrm{C}_{14}$ and $\mathrm{C}_{16}$, Journal of Chemical Thermodynamics, 37 . 941-953, 2005.

Salo, K., Jonsson, A. M., Andersson, P. U., and Hallquist, M.: Aerosol volatility and enthalpy of sublimation of Carboxylic acids, J. Phys. Chem. A, 114, 4586-4594, 2010.

Sempere, R. and Kawamura, K.:. Comparative distributions of dicarboxylic-acids and related polar compounds in snow rain and aerosols from urban atmosphere, Atmos. Environ., 28, 449-459, 1994.

Simoneit, B. R. T., Schauer, J. J., Nolte, C. G., Oros, D. R., Elias, V. O., Fraser, M. P., Rogge, W. F., and Cass G. R.: Levoglucosan, a tracer for cellulose in biomass burning and atmospheric particles, Atmos. Environ., 33, 173-182, 1999.

Solomon, S., Qin, D., Manning, M., Chen, Z., Marquis, M., Averyt, K. B., Tignor, M. and Miller, H. L. (Eds.): Contribution of Working Group I to the Fourth Assessment Report of the Intergovernmental Panel on Climate Changes, Cambridge University Press, Cambridge, 2007.

Stein, S. E. and Brown, R. L.: Estimation of normal boiling points from group contributions, J. Chem. Inf. Comp. Sci., 34, 581-587, 1994.

Thalladi, V. R., Nüsse, M., and Boese, R.: The Melting Point Alternation in $\alpha, \omega$-Alkanedicarboxylic Acids, J. Am. Chem. Soc., 122, 9227-9236, 2000.

Tsonopoulos, C.: Properties of Dilute Aqueous Solutions of Organic Solutes, Ph.D. Dissertation, University of California, CA, USA, 1970.

Yalkowsky, S. H.: Solubility and Partitioning. 5. Dependence of Solubility on Melting-Point, J. Pharm. Sci., 70, 971-973, 1981.

Zardini, A. A., Krieger, U. K., and Marcolli, C.: White light Mie resonance spectroscopy used to measure very low vapor pressures of substances in aqueous solution aerosol particles, Optics Express, 14, 2006.

Zhang, Q., Jimenez, J. L., Canagaratna, M. R., Allan, J. D., Coe, H., Ulbrich, I., Alfarra, M. R., Takami, A., Middlebrook, A. M., Sun, Y. L., Dzepina, K., Dunlea, E., Docherty, K., DeCarlo, P. F., Salcedo, D., Onasch, T., Jayne, J. T., Miyoshi, T., Shimono, A., Hatakeyama, S., Takegawa, N., Kondo, Y., Schneider, J., Drewnick, F., Borrmann, S., Weimer, S., Demerjian, K., Williams, P., Bower, K., Bahreini, R., Cottrell, L., Griffin, R. J., Rautiainen, J., Sun, J. Y., Zhang, Y. M., and Worsnop, D. R.: Ubiquity and dominance of oxygenated species in organic aerosols in anthropogenically-influenced Northern Hemisphere midlatitudes, Geophys. Res. Lett., 34, L13801, doi:10.1029/2007GL029979, 2007. 